\title{
Ethnography, Torture and the Human Terrain / Terror Systems
}

\author{
Neil L. Whitehead
}

Anthropologists are currently working on topics to do with the military or security apparatus, either for those institutors or as part of university based research programs. They are also studying warfare and conflict as sociocultural phenomena, in which ethnographic information about the contemporary military and security apparatus has not yet played a significant role. Certainly analysis of the socio-cultural phenomena of war or other armed conflicts might be improved by a better integration of ethnographic accounts of modern war and counter-insurgency operations but the fact that ethnographic practitioners in these contemporary military and security contexts conceived of themselves as "applied" anthropologists also raises critical issues as to the relation of ethnographic practice to ethnographic theory.

By their very nature situations in which violence is exercised are likely to be ethnographically opaque precisely because witnessing is a form of entailment in such violent acts (Whitehead 2004). However, the urgency and importance of responding to wide cultural concern over violence in general, as well as the immediate matter of "wars on terror" in Iraq and Afghanistan, makes this conundrum of ethnographic practice all the more relevant to address in the context of military and security situations. This set of intellectual questions is in turn overlaid by unfolding events as the military and security apparatus turns to the social sciences, particularly anthropology, for various kinds of active assistance in these policies.

This assistance ranges from direct recruitment of anthropologists into the military or security services, through to various types of consultancy and co-option, as well as fairly general calls for attention to government funded programs of research relevant to these ends. For some anthropologists this situation has evoked earlier, unhappy instances of such collaboration from the Second World War onwards (see David Price 2008), but in one sense this is nothing new, as Talal Asad (1973) pointed out in his classic collection of essays on the relation between anthropological theory and colonial practice. However, given this history the conscious choice to aid the military and security institutions of the United States is a matter current concern, not least because of the vulnerability of underemployed scholars and grant-less graduates. A better understanding of the nature of ethnographic practice, the need to provide adequate answers to ethical issues of how research may be conducted with integrity and nonpartisanship, and the recognition that the practice of violence is critical ream of human meaning that anthropology cannot afford to ignore the uncomfortable questions the call for "weaponizing culture" has raised.

Moreover, there is still a vast field of anthropological research that has yet to come to terms at all with its potentially neo-colonial orientation. Economic aid, social development, human rights, medical salvation, are all part of the perceived "benefits" that go along with liberal capitalist economics, and anthropology is often co-opted in delivering them. In this way ethnography is central to the cultural and political interface with others and a key reason why, despite rather impoverished theory, the results of anthropological field work are often still very welcome to other disciplines, as well as non-academic agencies, all too aware of their lack of cross-cultural perspective.

Anthropology provides the voice of the other and makes plausible the possibility that others can be influenced, reformed, developed or converted into appropriately obedient neo-liberal subjects. Although, as with racism, "culturalism" (an insistence on the ontological and experiential autonomy of differing cultural worlds) avoids reifying cultural difference, this paradoxically then makes it more difficult to perceive those cultures as historically 
and dynamically changing systems. Instead a "culture" appears as an aggregation of universalized human subjects ready to interact with other such individuals through the medium of a particular and individualized, rather than a collective and intertwined, cultural heritage

So cross-disciplinary or extra-academic collaborations may entail un-theorized risks and drawbacks for anthropology, just as ethical dilemmas quickly emerge from fieldwork. This is particularly true as performed under the current political conditions of war in Iraq and Afghanistan, but in many ways no less than with other forms of "engaged" anthropological work, such as with NGO's or international aid agencies. An urgent and important context in which these issues currently come together for anthropologists is the current military and security agency efforts to recruit anthropologists to assist as "cultural specialists" in the war-on-terror and even combat field operations in Iraq and Afghanistan. Although at this moment the recent change in administration is thought by some to herald the end of these wars, it is by no means clear that this will happen any time soon. In any case the fundamental ethical and epistemological issues provoked by deploying ethnography as a military strategy are, as I hope to make clear, perennial and inevitable without more adequately theorizing the historical and disciplinary legacies within which anthropology arose and from which it has yet to detach itself.

\section{| Military Imaginaries \& Ethnographic Practices}

The term "military imaginaries" is not meant to imply some form of wishful thinking as to the relationship that the military and security apparatus wants to initiate with anthropology. Rather the phrase implies that the idea of ethnographic knowledge as a form of ready-to-use military intelligence is part of a faulty understanding, symbolically powerful though it may be for professors no less than generals, that scholarship readily produces actionable policy. But can anthropology actually do what the military and security institutions imagine?

The view that it can (and should) has been widely promulgated of late. However there is a mutually seductive reasoning at play here. Since military planners are looking for a means to fix a perceived lack of battlefield intelligence, and anthropologists are looking to make anthropology relevant to major political events, the idea that ethnography could be a magic-bullet to offset the failure of existing counter-insurgency strategies in Iraq and Afghanistan seems irresistible.

So we are faced with two related questions as to not only the ethics of ethnographic practice but also as to the limits and possibilities of ethnographic research itself. Nor is this latter issue a mere question of theory or epistemology but an issue which has direct and even tragic consequences as anthropologists are recruited to service in combat zones, as with the Human Terrain Systems (HTS) program - http://humanterrainsystem.army. mil/default.htm. By promoting the idea that "ethnography-to-go" can effectively generate new tactical and strategic options for commanders in a battle-zone, both anthropologists and military planners are endangering ethnographers and soldiers alike.[1]

However, this form of ethnographic engagement in military operations is distinct from wider issues of how anthropology and ethnography might be deployed at other points in the "kill-chain", or, perhaps more saliently, at the level of policy making with regard to military action. In this context, historical and cultural studies of societies that have transitioned through colonialism, military occupation, or civil war may be more relevant for policy making in Iraq or Afghanistan than "classic" ethnographic studies of their past clan politics, or kinship systems.

This was precisely the conclusion and relevance of an earlier anthropological analysis of colonial and neocolonial warfare War in the Tribal Zone (Ferguson \& Whitehead 2000) which at the time of the U.S. invasions of Haiti, Grenada and Somalia, attracted interest from the U.S. State Department. This work examined the way in which state expansion across a global range of societies and historical epochs had regularly generated certain kinds of socio-cultural phenomena, these processes being summated through the idea of a cultural landscape termed a "tribal-zone", indicating the socially generative effects of militarily inflected colonial processes. This underlines the way in which military action itself has a dynamic impact on the very socio-cultural relations that ethnographers are being deployed to report on. Against a rapidly changing cultural and social backdrop induced by the military ethnographic presence, the practice of ethnography itself becomes highly problematic, especially where it seeks to delineate the very phenomenon that it is a part of changing - consciously or not. The conclusions of War in the Tribal Zone, to the effect that military invasions to produce specific political results were inevitably apt to flounder due to a logic of mimetic violence in warfare, was an insight that would not better enable such operations at all, but 
rather should encourage a search for policy alternatives.

I would contend that the result of most (if not all) anthropological assessments of operational procedures (military or otherwise) is broadly going to be the same. Thus the "ethnographic data" produced by fieldwork to service a particular policy option is inherently flawed since certain theoretical frameworks (such as that in War in the Tribal Zone) are inevitably discounted in its production. After all, it would be nonsensical and contradictory to undertake a study of, for example, how to better deliver food or medical aid amongst a civilian population that was thought to harbor rebels or insurgents if the results of that research were likely to suggest that the distinction between civilian and insurgent was not possible to sustain in a way that illuminated either local identity practices or local policy options. So either one does not do such research or one does it badly, as a best-fit compromise, with a varying consciousness and ethical concern about such a process. This is where the insidious justification of "harm reduction", a favorite of military and security apologists, enters the discourse and allows the individual researcher to adjust their professional ethics to meet a policy need.

So in fact, and despite irresponsible and widely publicized claims to the contrary (McFate 2005a, 2005b), ethnography amongst "insurgent" populations for the military is probably the least useful activity that anthropologists might conduct to assist both military operations and government policy making. Ethically then the issue is not just as to whether or not a duty of confidentiality and responsibility towards one's informants entails that acting from the position of invading/occupying military represents a breach of such trust, but also whether those claiming and encouraging participation by anthropologists are likewise ethically responsible. Those anthropologists most likely to participate in such military or security programs in my experience are likely to be those vulnerable because of the wider lack of job-security and opportunity in the profession, such as recent PhD's or even graduate students. While participation in the HTS program is not a "suicide-mission" the death-rate amongst participants seems high.[2] In short, the long-term, intimate, and historically inflected positionality of the ethnographer is not at all well suited to operational or combat military needs. Ethnography of the military and of its enemies as collectivities therefore emerges as a feasible intellectual option in the way that battlefield ethnography for particular combat purposes does not. In this way the objections to programs like HTS are not just the possible ethical conflicts of interest, which can arise in many other forums of research, but also the likelihood that it cannot work in the way it has been erroneously promoted to do by some anthropologists (see McFate), as much as by politicians and the high-level military.

Nonetheless, the Pentagon MINERVA program envisages just such a broad academic and military collaboration, not necessarily tied to the immediate hope that HTS will allow for political and military progress in Iraq, Afghanistan and beyond. It was recently announced by Defense Secretary William Gates that the new project, named after the goddess of wisdom and war, would involve universities in the global "war on terror".[3] This kind of government program raises different kinds of issues and ethnographic practice in combat zones, but is only a minor component of the intellectual scope of this initiative. MINERVA envisages a wide range of data analysis and theoretical modeling, rather than initiating the collection of particular kinds of information as with the HTS program. Secretary Gates gave the examples of what might constitute fundable activities under this program by citing three major areas of interest: Chinese Military and Technology Studies, Iraqi and Terrorist Perspectives Projects, and Religious and Ideological Studies. Anthropologists' involvement in such programs takes on a different character to that of on the ground participation in the HTS program, but one which may nevertheless be equally problematic, ethically and even epistemologically.

Historically and politically the use of academic research by government is hardly controversial, except to the extent that, as citizens, anthropologists also have political opinions and beliefs about government and what it should or should not do, so that participation in MINERVA programs is but one example of how Federally funded research is carried out in American academe. Ethically anthropology is therefore not alone and indeed is already required by the Federal government to have research projects reviewed for possible impacts on human subjects, wider questions as to the nature of research priorities are therefore not separate from political judgments as to the goals of academic knowledge or research projects more generally. Equally, anthropology, as in the case of HTS ethnography, is not a privileged route to achieving impossible political goals. No amount of anthropological research is going to "solve" the Palestine-Israel conflict or suddenly cause Islamic jihadist to love America, but it can inhibit poor policy choices, influence development aid programs, and perhaps even change strategic military planning but only if the political choices are made that go along adopting such new goals and aims. To a degree then there is an opportunity for anthropologists to speak with significant voice in national policy debate but this is in the same way that doctors, psychiatrists, lawyers, and other professionals already do - also with varying degrees of personal political commitment 
to existing or future policy options.

Even with broader programs of research that do not carry the special ethical and research concerns that ethnographic study of populations in combat zones for the military might do, there are still very salient ways in which ethical responsibilities to the subjects of anthropological research are also present. The recent analysis and recommendations of the AAA Commission on the Engagement of Anthropology with the US Security and Intelligence Communities emphasizes the both the opportunities and perils of such engagements. [4] However, although the case of engagement with military and security institutions is the central concern, it is important to appreciate that MINERVA really only represents a codification of disparate research already being done under a wide range of sponsored programs. In any case, research undertaken using Federal money is always available to whomever wishes to consult it; "just publish" may therefore be quite sufficient to realize certain government / academic collaborative ends.[5]

In a similar vein, and apparently overlooked in debates as to the ethics of military engagement, was the recent controversy within the AAA itself over paramedical research conducted with funding from the Atomic Energy Commission This research program was at best poorly planned, and at worst so cynically conceived that it apparently resulted in a number of deaths amongst the indigenous population of the Venezuelan Amazon. The final report of the AAA's own commission was not adopted[6] and the circumstances of both accusations and rebuttals remains murky, but the case illustrates a important additional consideration: that the perceived conduct of anthropological research is as important as the integrity of the mechanisms and bureaucracies that oversee ethical research, precisely because we deal with human subjects. For this reason many anthropologists see the potential benefits of closer engagement with government policy as always potentially offset by other (even if misconstrued) perceptions of that relationship. [7] Indeed, one other arena of government sponsored research that - until now at least - has not attracted the same degree of professional scrutiny, although it arguably should, is the Department of Homeland Security's various research initiatives. It should not be forgotten, from the point of view of anthropological ethics and practice, that research internal to the United States may be potentially as problematic for anthropologists who are widely engaged in ethnography of various "homeland" populations, as has proved the case with ethnography among "foreigners." [8]

\section{Ethnography, Torture and Epistemologies of Conquest}

"So, pesquisa (field research) is a thing that doesn't declare what it is. No, it doesn't declare what it is... pesquisa hides many things." (Brasilino Anício da Silva)[9]

Among the many questions provoked by the way in which ethnography's potential for "weaponization" is revealed in security and military overtures is the need for a critical examination of the practice of ethnography by anthropologists in other contexts of collaboration with government agencies. The refusal of marginal populations to become legible to the State or its institutions of government is globally evident in the way in which such agencies may be resisted at a local level. This resistance is made apparent through the way in which popular support is often given to those branded as criminal, rebel or insurgent (Hobsbawm 2000), or through the global phenomenon of the physical retreat and avoidance of government by indigenous peoples (Bodley 2008), or even through the mundane practices of daily life (Nash 1993, Scott 1985). Social conformity is calculated, not unthinking, and beneath the surface of symbolic and ritual compliance there is often an undercurrent of resistance or effacement of actual intentions. In such circumstances deploying ethnographic information for purposes of colonial occupation or the enforcement of State power need not be a self-conscious or politically overt aspect of State agency since ways of knowing, as much as the knowledge they produce, are culturally shared amongst the agents of State power. The professionalization of anthropology in the early 20th century therefore detached ethnographic information gathering from this kind of governmental project and re-invented it as a systematic and scientific technique. The un-systematized knowledge and interpretation of the agents of the government apparatus was downgraded by a newly-scientific anthropology to the status of travelogue, memoir or as simply lacking credible insight.[10]

Certainly these were valid criticisms but it is the genealogy of ethnographic knowledge that is relevant to consider here, as well as the way in which the newly "scientific" voice of ethnography might be re-attached, recruited, to the purposes of government, as in the case of the HTS program or other of the current projects for utilizing social science knowledge. Whether or not anthropology has critically engaged this legacy to a sufficient degree is therefore 
tested in considering the difficult and perhaps unwelcome questions as to why we pursue the knowledge goals we do, the nature of the methods we use to fulfill those goals, and whether or not those goals are the appropriate ones for a post-colonial anthropology[11] that is not to become unwittingly entailed in the projection and inscription of State power (Gordon 2007, Smith 1999).

A unwitting or undesired co-option of existing ethnographic research into military planning or even the application of torture is therefore an alarming prospect for most anthropologists but is also a reflection of the epistemological character of ethnography itself. Exactly these concerns are evident in the debates and discussions of the possible use of a particular ethnography in the torturing of prisoners in Iraq. In a series of articles in The New Yorker magazine the journalist Seymour Hersh suggested that the anthropologist Raphael Patai's The Arab Mind $(1976,2007)$ had been used by interrogators. In fact this seems doubtful and in discussion of the Patai / Hersh materials nearly all commentators, whatever they think as to the factual issue of whether Patai's work was known and employed by torturers, express outrage and shock at the idea that ethnography might be used in this way. Certainly the prevalent professional assumption would be that that the progressive, advocacy or human justice goals of ethnographic representation would insulate and inoculate ethnography against being used in this way. Of course not all ethnography is informed by the same values[12] but to the extent that an ethnography has this character we may still be blind to the epistemological origins and character of the anthropological research agenda which historically informs our practice.

In my own ethnography of sorcery and mystical killing (Whitehead 2002a) this was a central issue. Cannibalism, assassination, and secret sects of sorcerers are all attention-grabbing themes and a decision to write about such topics inevitably reproduces colonial categories of understanding to some degree. This also has material consequences in that through writing about this sect - the kanaimà - I was also supplying the kinds of information that could be used by police agencies to identify specific individuals associated with particular killings. For this reason all names in the ethnography were changed but could have been easily reconstituted by anyone with a degree of local knowledge. This was the outcome that local people also desired since some of them were very much in favor of having the kanaimà investigated by the police, others were at the same time concerned as to what the wider effects of such a police presence might entail. Pragmatically I knew that the Guyanese police force did not have anything like the resources (or interest) in such investigations but this does not obviate the problem of how forms of ethnographic representation and analysis might simultaneously service police, government, and security purposes. Nonetheless, I have argued that a critical engagement with this colonial archive of representation is possible and needed.[13] As a result, it becomes possible to envisage new forms of ethnographic engagement that are more strongly driven by local needs and interests rather than the unexamined agendas of the institutionalized profession of anthropology. It is quite clear that these difficulties and the need to search for alternatives is well understood by many anthropologists, but what is less clear is if we have fully appreciated the depth of the problem we face, given the consternation expressed by anthropologists about the claims of Seymour Hersh. The work of many anthropologists engaged with issues of the military and warfare is exemplary in this regard since they identify new objects of ethnographic interest and new forms of ethnographic engagement with military and security worlds that do not confine us to a simple binary of researching for the military or taking military institutions and practices as our only ethnographic context. [14]

In short, it is the character of our participation not just of our observation in other's worlds that needs to be examined and, with a greater emphasis on thinking about how we participate in other cultural situations, as well as what our knowledge goals are in such situations, many of the dilemmas of research presented by the historical legacies of ethnographic practice can be resolved. In particular the "ethical" issues as to participation in a HTS team or other such military / security programs becomes less of an abstract issue of commitment to the idea of democratic government or academic scholarship, and more of an inter-subjective issue as to how one conducts oneself as a person in the world, in whatever social roles we perform..

As with other disciplines that interact with people, anthropology is only publicly comfortable with certain kinds of inquiry - broadly those that do not entail deception and physical or mental harm - and for which the Human Subjects Review Panel / IRB functions as a form of licensing. But as the public debate over torture showed us, we can easily revise those preferred parameters if the urgency and need is thought to be sufficiently pressing. As with the case of the Tuskegee Experiment or the MK-Ultra program, we do not need the excuse of active war to countenance all kinds of special or extraordinary governmental actions. This debate also challenged many received understandings of what might constitute "torture" as opposed to "enhanced interrogation technique", but, as Lazreg (2008: 6) 
writes, “...discussions of what degree of physical punishment rises to the level of torture ... generally constitute preliminaries to defending torture as a legitimate form of interrogation." What is unsettling here for anthropologists is that, as with torture, the purpose of ethnography is the gathering of information, data and knowledge of others, who might be either enemies or allies of the government apparatus in the ethnographer's homeland. How then is ethnographic interrogation different from military torture or is there a hidden epistemological convergence between torture and ethnography? This analogy, although very difficult to countenance given the way in which ethnography has been used to produce so many key insights into many forms of oppression and exploitation world-wide, cannot be lightly dismissed. At stake is our "right-to-know" things, even where such things are kept hidden purposefully (kinship), are only talked about with pain (memories of war, killings, witchcraft,) or where there is a cultural silence and "knowledge" that is as yet unarticulated (personal motives, life-histories, collective purposes);

"This was what made the Atchei savages: their savagery was formed of silence; it was a distressing sign of their last freedom, and I too wanted to deprive them of it. I had to bargain with death; with patience and cunning, using a little bribery... I had to break through the... passive resistance, interfere with their freedom, and make them talk" (Clastres 1998:97)

In Chronicle of the Guayaki Indians, Pierre Clastres stresses the profound significance of Atchei-Guayaki silence in the face of ethnographic inquiry, seeing it as the foundation of their continuing autonomy, "health" and "freedom";

"The society of the Atchei... was so healthy that it could not enter into a dialogue with me, with another world. And for this reason the Atchei accepted gifts that they had not asked for and rejected my attempts at conversation because they were strong enough not to need it; we would begin to talk only when they got sick." 1998:97).

Clastres further engages this threatening isomorphism of torture and ethnography and the "breaking" of savage silence in his essay Of Torture in Primitive Societies, in which he argues that the tortured body is meaningful only when silent suffering comes to express courage and assent to the torture itself, as in initiation (1989:184-185). Indeed we do have a terror of the silence of the "savage other", which torture if not ethnography must rupture, for this silence, this absence of explanation or rationality, is part of what is terrifying about terrorists.

In Western cultural tradition, our desire to speak and to be heard stems from the Enlightenment understanding of the cultural and historical foundations of our Cartesian notions about individual existence - to think (i.e. to speak) is to be human. As a result the absence of speech, or its failure to become intelligible (a literal "barbarism"), means that silence potentially operates as a form of terror and resistance. Silence threatens our ideas about the humanity of being and may even suggest non-being, or "inhumanity". Silence is also a sign of death, but perhaps also the prelude to re-birth. The monk's vow of silence that leads to spiritual re-birth, the rehabilitatory silence enforced on prisoners, and also the anthropologist, who becomes silent culturally through removal to other places, and whose return is marked by an almost excessive narration. The establishment of professional ethnographic credentials therefore takes place through the un-silencing of the now "researched" other.

Like ethnography then, torture overcomes the silence of the resistant other, and like torture the results of ethnography are epistemologically problematic, notwithstanding the undergirding justifications of professional academic research and scientific knowledge. As Derek Freeman (1999) showed in re-evaluating Margaret Mead's breaking of the Samoan silence, or with Napoleon Chagnon's (1974) avowedly deceptive tactics for learning Yanomamö kinship relations, the broader significance of the ethnographic question as a token of power relations means the agonistic process of inquiry, in both torture and ethnography, can never produce the kinds of knowledge we culturally desire.[15]

The Greek term for torture was basanos, literally meaning an assay or testing of metals for their purity. This agonistic view of how knowledge is produced was part of the Enlightenment revival of Classical thought. The ancient Greeks routinely tortured slaves to extract evidence for legal trials. They considered truth obtained from slaves by torture to be more reliable than the freely-given testimony of free men. So may question whether recollection of this fact is merely a curiosity that allows us to marvel at our progress from the past, or whether our very idea of truth, the truth of the philosophical tradition founded by the ancient Greeks, is caught up in the logic of torture, in which truth is conceived of as residing elsewhere, requiring violence and suffering as necessary for its production (duBois 1991).

The early modern "discoverie" of witchcraft (Scot 1584) throughout Europe was an ethnographic exercise partly serviced by the information gathered through systematic torture.[16] Likewise the dissection of executed criminals, and the auto-dissections by the surgeons themselves culturally sustained this linking of knowledge and 
physical torment into the 18th century. In the 19th century the scene of torture and torment as a fount of truth was re-located to the agonies of creative and intellectual production, as in the emotionally intensity and even selfdestruction of the Romantics. The figure of the tormented and tortured genius, like Edgar Allan Poe, was a staple of the 19th and 20th century imagination, just as human or animal suffering in scientific experimentation can also be pictured as the (acceptable) price of progress. Such examples signal the continuing cultural importance of founding truth in agonistic performance (Guyer 2007), just as the cultural centrality of the crucified Christ sustains yet another linkage to the association of torment with spiritual truth (Cavanaugh 1998), as well as with ethnographic truth (Whitehead 2008). This then is also the import and "truth" of the human qualities revealed in other cultural practices such as the Hellenisitcally inspired Olympic Games, which themselves originated as an explicit proxy for war.[17] The massive cultural and economic presence of "sport" world-wide replays this ideology weekly if not nightly in the sport sections of every news outlet, to say nothing of the global industries that service consumption and participation in sport and physical recreation. No pain, no gain in these cultural realms, or in the torture room.[18]

It is quite correct to point out that the as a device for collecting particular and accurate information the theater of torment we know from such contexts as Algeria, Guatemala or Chile, does not work. These violent performances are a form of a ritual meant to dramatize and empower the state or its agents, while marking and ontologically possessing the victims, as Scarry (1987) has pointed out. In this way our displacement of bodily torment into other cultural realms appears as a progressive and enlightened cultural development, or at least it did until Abu-Ghraib and Guantanamo. However, the eruption of support in the Untied States for the need to torture, aka "enhanced interrogation techniques", suggests that the ritual of torture might also validate and discover truth in a different way. Not the truth to the torturers question (Alleg 1958) but the truth of the ideas and institutions for which the victim is tortured. Debates as to the effectiveness of interrogation techniques must take account of not only this performative element but also the relation between agony and truth, or risk becoming akin to those debates as to what degree of mental or physical suffering rises to the level of torture. Expressed through a "lexicon of terror" (Feitlowitz 1999) these ghoulish debates are the direct intellectual descendant of the manuals of ethnography and torture through which earlier imaginaries of covert and unreasoning social opposition and physical threat were discovered and interdicted. As Sartre (1958) observed of French torture in Algeria, it is a means for the creation of an other. In the case of contexts like Abu-Ghraib or Guantanamo, the creation of an insurgent, terrorist other, whose coming into existence through torture then validates the "truth" of a "Mission Accomplished" for American democracy in its "War on Terror".

\section{| The End of Anthropo-logy}

As Franz Kafka's (1977) famous story "In the Penal Colony" makes graphically evident, there is also a relationship between social legibility and bodily inscription. There are two central characters in Kafka's story - the Traveler (as ethnographer) and the Officer as (exotic other). In the story the execution of prisoners transported to the Penal Colony is carried out by them being laid out on the bed of a machine which then inscribes, through the cutting of their flesh and dismembering of their bodies, the nature of the prisoner's crime. Foreshadowing the tattoos of the Nazi extermination camps but recalling the relation between tattooing, torture and writing in the Hellenistic world (duBois 1991: 69-74) the torture victim is marked bodily as a means of rendering rebellious subjects visible as servile and broken both to themselves and to others. As with the risk of mere prurience masquerading as "scientific" or "humanistic" interest in observing and representing the sexuality and violence of others (Whitehead 2004, Whitehead \& Sigal n.d.), so the passionate but passive witnessing of the testimonies of the tortured and suffering may nonetheless be an ethnographic "finger in the wound" (Nelson 1999). The ethnographic production of narratives of victimhood and the possibility of inscribing others into such ethnographically constructed identities may "only" provoke a psychological mimesis of the original moment of violence, but it is a source of suffering nonetheless (Kleinman, Das \& Lock 1997).

At the heart of darkness there is only a silence, for the core of the other is unspeakable (unknowable) so there is only Kurtz's cry of "The horror! The horror!" (Conrad 1988). This is the gasp of shock in the presence of ineffable violence that also signals terrorism, as on 9/11, or in the spectacle of "suicide-bombing", ethnic cleansing and even homegrown serial killing. But it is the opaque and mysterious nature of such violent actions that legitimates the violence of our response, our need to make them also gasp in shock and awe (Whitehead \& Abufarha 2008). If we 
are speechless with horror then why should they be allowed a voice?

Professionally the response of anthropologists has often been to seek collaborative and overtly dialogical forms of ethnographic engagement. In which case it is the interest and attitudes of those studied as much as the questions which drive doctorates and advanced research programs that will come into play. Whether or not the "knowledge" so generated is worth anything on the academic market is a different question, since the fundability of particular kinds of research obviously influences professional choices and career success. So the critical question for the issue of anthropology's potential military and governmental involvement becomes one as to whether or not these kind of collaborative methodological practices are ethically sufficient to avoid the practice of torture as ethnography. As Pierre Clastres (1998:96) reflected on the historical silence of the Atchei; "I remembered what Alfred Métraux had said to me not long before: For us to be able to study a primitive society it must already be starting to disintegrate.” It is also then necessary to ask if such methodological practices disable the kind of colonial purposes which anthropology and society have long shared. In both cases the answer can be "yes" - since collaboration and dialogue allow space for the mutual agreement of "knowledge goals" and at the same time this methodological practice breaks with the idea of "knowledge" as philosophically restricted to Western forms of understanding and interpretation. The notion of the "human" has been central to such an epistemology so that the unraveling of the colonial epistemological project also suggests the simultaneous unraveling of its central subject/object, and this has been precisely the investigation of the logos of anthropos around which the discipline formed. For these reasons it is time to enact a post-human anthropology (Whitehead 2009), an anthropology of persons in which the resistant subject no longer has to suffer the cultural interrogation of the ethnographer.

\section{Endnotes}

1. This is tragically illustrated by one of the first deaths of an anthropologist working for the HTS program, Paula Loyd. The memorial statement posted at the HTS web-site makes evident the critical failing of the idea of ethnography-to-go and, despite Paula Loyd's four years of experience in Afghanistan, how dynamic processes of war can render irrelevant ethnographic understandings deriving from more peaceful times or places: "After conducting a number of interviews in the bazaar, Paula began interviewing a man who was not from the local village about household economic issues, including the price of fuel. The man was carrying fuel in an open pitcher covered with a cloth, which is a common practice in rural Afghanistan. During the 15-minute interview, the man appeared gregarious and non-threatening and thanked Paula and her teammates multiple times in English for the work they were doing in Afghanistan. Without any warning, the man Paula had been interviewing doused her with the contents of the fuel canister and set her on fire...Tragically, Paula was unable to recover from the severe burns she sustained, and died on January 7, 2009 surrounded by her loved ones." (http://humanterrainsystem.army.mil/ paula.html) Two other anthropologists have been killed to date and are also memorialized at the HTS website; Michael Bhatia and Nicole Suveges. In both cases they were killed by explosive devices and no amount of "ethnographic insight" seems likely to have averted this - see accounts at http://humanterrainsystem.army. mil/nicole.html, http://humanterrainsystem.army.mil/ bhatia.html
2. I have interviewed a number of veterans and stillserving military personnel in the Afghan conflict whose personal opinions were unanimous in suggesting that the HTS personnel, whatever good they were doing, were very vulnerable through a general lack of military experience.

3. Although that particular rhetorical phrase may disappear under the advent of a Barack Obama administration, William Gates remains Defense Secretary, and in any case The Department of Defense has announced the first round of awards in its Minerva Research Initiative. The newly announced grants, which the Pentagon says might total \$50-million over a five-year period, have been given to seven principal investigators... "more than 16 academic institutions, including three non-U.S. institutions, are expected to participate in the seven research efforts." The seven projects, chosen from among 211 proposals, were reviewed by the department. The Pentagon has also provided money for a closely related NSF program (Social and Behavioral Dimensions of National Security, Conflict, and Cooperation (NSCC) Program Solicitation - NSF 08-594) in which proposals are being reviewed through the National Science Foundation's merit-review process. Awards picked by the NSF are expected to be announced in January. David Glenn, Chronicle of Higher Education, December 23, 2008. http://chronicle.com/news/article/5711/pentagonannounces-first-grants-in-disputed-social-scienceprogram.

4. The full text of the report is available at http://www. 
aaanet.org/cmtes/commissions/CEAUSSIC/index. $\mathrm{cfm}$.

5. However, medical anthropologists, for example, have been led to question even such broader aspects of medical and ethnographic research, as was notoriously the case with the Tuskegee experiments that ended in the 1970 s but also in other contexts continuing through to current research programs on AIDS and HIV infection. Currently there are deep concerns as to ethnographically based medical research amongst marginal or vulnerable populations in the Caribbean and West Africa (Wendland 2008). This arises because the sponsored study-design calls for those treatments being given in American or European hospitals to be replaced with treatments deemed more appropriate to the financial and medical resources of the local population. The purpose of the research design is to evaluate the feasibility and cost basis of these less effective treatments as an alternative to the costly and technologically more sophisticated American and European treatment regimes, and as such are seen by some as a legitimate reduction of harm.

6. See - http://www.aaanet.org/stmts/05ref_eldorado. htm and for the report and supporting materials see - http://www.aaanet.org/issues/policy-advocacy/ Preface-for-El-Dorado-Task-Force-Papers.cfm

7. For example, materials relating to this controversy were posted on a web-site run by the Chilean Mapuche tribal organization - http://www.mapuche.info/ mapuint/AAA01.html

8. See - http://www.dhs.gov/xres/ for a description of these programs "on a variety of threats that include agricultural, chemical, biological, nuclear and radiological, explosive and cyber terrorism, as well as the behavioral aspects of terrorism".

9. Amazonian Caboclo (river-gypsy), Lago Grande Rio Negro September, 2005 excerpted from the field recordings of Kent Wisniewski.

10. Nonetheless scientific taxonomies shaped both nonfictional and fictional narratives. Thus novels invoked the language of science to lend authority to the project of literary realism (McBratney 2005) and travel writing and memoirs usually offered scientific observation as a token of the travelers' authenticity (Whitehead 2002b).

11. Linda Tuhiwai Smith (1999) important discussion of "decolonizing methodologies" and Lewis Gordon's (2007) analysis of "disciplinary decadence" both point to the need to re-think inherited methodologies and disciplinary categories by examining the openness of ideas and purposes from which their disciplines were born.

12. See Robert Edgerton's Sick Societies (1992) for example or Napoleon Chagnon's (1968) famous ethnography of the Yanomamö, or Christopher Hallpike's (1979) account of the Tauade in Papua New
Guinea, reviewed by Andrew Vayda (1979)

13. This is also the case with other topics, such as sexuality, where a similar critical exercise in under way see Whitehead \& Sigal (n.d,.).

14. A range of ethically complex forms of ethnographic engagement directly with the military inform developing anthropological debates on military cultural expression in the form of "grunt lit" (Brown \& Lutz 2007), or YouTube videos, as well as the phenomenon of a culturally expansive militarism itself (Enloe 2007, Finnström 2008, Nordstrom 2004) and the media and virtual worlds of disembodied war and its production as mass spectacle (Robben, Stein 2008).

15. The Greek term for torture was "basanos", literally meaning an assay or testing of metals for their purity. This agonistic view of how knowledge is produced was part of the Enlightenment revival of Classical thought.

16. The most influential manuals on witch-finding, like Scot's Discoverie, the Malleus Maleficarum (Hammer of the Witches) of Heinrich Institoris, or the Praxis Criminalis by Prospero Farinacci, offered protocols for early modern courts in investigating cases of maleficium (sorcery, witchcraft). Such manuals laid out the role and function of torture within the system of constructing and justifying truth in court with a resulting impact on patterns of evidence production and interpretation. The Praxis is most noteworthy as the definitive work on the jurisprudence of torture while Scot's Discoverie was highly ethnographic being a compendia of local and folk beliefs and practices that were designed to allow better discrimination between the harmless and the evil, a form of "Spiritual Terrain System".

17. The International Olympic Committee (IOC) was founded in 1894 by a French nobleman, Pierre Frédy, Baron de Coubertin, Despite what Coubertin had hoped for three Olympic Games in 1916, 1940 and 1944 were cancelled because of World Wars.

18. The agonistic qualities of the cultural notion of "truth " are but part of the wider "regime of truth" to which Foucault refers as being "...produced only by virtue of multiple forms of constraint." (1972: 131) 


\section{References}

Agamben, Giorgio. 2003 The Open: Man and Animal. Stanford: Stanford University Press.

Alleg, Henri. 1958 The Question. New York: G. Braziller.

Asad, Talal (ed.). 1973 Anthropology \& the colonial encounter. London: Ithaca Press.

Atlan, de Henri and Frans B. M. De Waal . 2007 Les frontières de l'humain. Paris: Editions le Pommier.

Badmington, Neil (ed.). 2000 Posthumanism. New York: Palgrave.

Bodley, John. 2008 Victims of Progress. New York: McGraw-Hill.

Brown, Keith. 2009 "All They Understand Is Force”: Debating Culture in Operation Iraqi Freedom. American Anthropologist 110(4): 443-453.

Brown, Keith and Catherine Lutz . 2007 Grunt Lit: The Participant Observers of Empire. American Ethnologist, 34(2):

Chagnon, Napoleon A. 1968 Yanomamö. The Fierce People. New York: Holt Rinehart and Winston.. 1974 Studying the Yanomamö. New York: Holt, Rinehart and Winston.

Clastres, Pierre. 1998 Chronicle of the Guayaki Indians. New York: Zone Books.. 1989 Society against the State: Essays in Political Anthropology. New York: Zone Books.

Conrad, Joseph. 1988 Heart of Darkness. New York: Norton \& Co.

DuBois, Page. 1991 Torture and Truth. New York: Routledge.

Edgerton, Robert B. 1992 Sick Societies: Challenging the Myth of Primitive Harmony. New York: Free Press.

Enloe, Cynthia. 2007 Globalization and Militarism: Feminists Make the Link. New York: Rowman \& Littlefield Publishers, Inc.

Farinacci, Prospero. 1676. Praxis, et theoricae criminalis. Nuremberg: W. M. Endteri, \& J. A. Endteri.

Feitlowitz, by Marguerite. 1999 A Lexicon of Terror: Argentina and the Legacies of Torture. New York: Oxford University Press.

Ferguson, R. Brian and Neil L. Whitehead (eds.). 2000 War in the Tribal Zone: Expanding States and Indigenous Warfare. James Currey / SAR Press: London /Santa Fe.

Finnstrom, Sverker. 2008 Living with Bad Surroundings: War, History, and Everyday Moments in Northern Uganda. Durham: Duke University Press.

Foucault, Michel. 1972 Power / Knowledge. (trans. Colin Gordon). New York: Pantheon Books.
Freeman, Derek. 1999 The Fateful Hoaxing Of Margaret Mead: A Historical Analysis of Her Samoan Research. New York: Basic Books.

González, Roberto J,. 2007 We Must Fight the Militarization of Anthropology. The Chronicle Review, 53(22): B20, 2/2/2007.

Gordon, Lewis R. 2007 Disciplinary Decadence: Living Thought in Trying Times. Boulder (CO): Paradigm.

Gusterson, Hugh. 2007 Anthropology and Militarism. Annual Review of Anthropology, 36: 155-175.

Guyer, Sarah. 2007 Romanticism after Auschwitz. Stanford: Stanford University Press.

Hallpike, Christopher R.. 1977 Bloodshed and vengeance in the Papuan mountains : the generation of conflict in Tauade society. Oxford: Clarendon Press.

Hobsbawm, Eric. 2000 Bandits. New York: The New Press.

Institoris, Heinrich,. 1588 Malleus maleficarum. Frankfurt: Nicolai Bassaei.

Kafka, Franz. 1977 The Penal Colony : stories and short pieces. Willa and Edwin Muir (trans.). New York: Schocken Books.

Kitson, Frank. 1973 Low Intensity Operations. London: Faber and Faber.

Kleinman, Arthur, Veena Das and Margaret Lock (eds.). 1997 Social Suffering. Berkeley: University of California Press.

Lazreg, Marnia. . 2008 Torture and the Twilight of Empire: from Algiers to Baghdad. Princeton: Princeton University Press.

Lutz, Catherine A. 2002 Homefront: A Military City and the American Twentieth Century. New York: Beacon Press.

McBratneyJohn . 2005 Racial and criminal types: Indian ethnography and Sir Arthur Conan Doyle's "The Sign of Four", Victorian Literature and Culture, 33(1): 149-167.

McCoy, Alfred W. 2006 A Question of Torture: CIA Interrogation, from the Cold War to the War on Terror. New York: Holt.

McFate, Montgomery. 2005a Anthropology and Counterinsurgency: The Strange Story of their Curious Relationship, Military Review, March/April: 24-38.. 2005b Does Culture Matter? The Military Utility of Cultural Knowledge, Joint Forces Quarterly, 38: 42-48.

Mentore, George. 2004 The glorious tyranny of silence and the resonance of shamanic breath. In Darkness and Secrecy; The Anthropology of Assault Sorcery and Witchcraft in Amazonia. Neil L. Whitehead and Robin Wright (eds.). Durham and London: Duke University Press. 
Nash, June. 1993 We Eat the Mines and the Mines Eat Us. New York: Columbia University Press.

Nelson, Diane M. 1999 A Finger in the Wound: Body Politics in Quincentennial Guatemala. Berkeley: University of California Press.

Nordstrom, Carolyn. 2004 "The Tomorrow of Violence", in Violence, pp. 223-42., Neil L. Whitehead (ed.) Santa Fe: School of American Research Press.

Nordstrom, Carolyn and Antonius C. G. M. Robben (eds.),. 1996 Fieldwork Under Fire: Contemporary Studies of Violence and Culture. Berkeley: University of California Press.

Patai, Raphael. 2007 The Arab Mind. (with Norwell B. De Atkine ), New York: Red Brick Press. 1976 The Arab Mind. New York: Sribners.

Price, David. 2008 Anthropological Intelligence: The Deployment and Neglect of American Anthropology in the Second World War. Durham: Duke University Press.

Ronson, Jon. 2006 The Men Who Stare at Goats. New York: Simon \& Schuster.

Sartre, Jean-Paul. 1958 Preface (in) The question, Henri Alleg. New York: G. Braziller.

Scarry, Elaine. 1987 The Body in Pain: The Making and Unmaking of the World. New York: Oxford University Press.

Scot, Reginald. 1584 The Discoverie Of Witchcraft. London: William Brome.

Scott, James C. 1985 Weapons of the Weak: Everyday Forms of Peasant Resistance. Yale: Yale University Press.
Smith, Linda Tuhiwai. 1999 Decolonizing Methodologies: Research and Indigenous Peoples. London: Zed Books.

Stein, Rebecca L. 2008 Souvenirs of Conquest: Israeli Invasions as Tourist Events. Int. J. Middle East Stud, 40: 647-669.

Vayda, Andrew P. 1979 Review of: Bloodshed and Vengeance in the Papuan Mountains: The Generation of Conflict in Tauade Society by C. R. Hallpike. American Anthropologist, 81(2): 424-425.

Wendland, Claire L. 2008 Research, Therapy, and Bioethical Hegemony: The Controversy over Perinatal AZT Trials, African Studies Review, 51(3): 1-23.

Whitehead, Neil L. 2009 Post-Human Anthropology. Identities: Global Studies in Culture and Power, 16(1): 1-32.. 2007 Violence and the Cultural Order. Daedalus Winter, 40-50. 2004 Violence. (ed.) Santa Fe: SAR Press.. 2002a Dark Shamans. Kanaimà and the Poetics of Violent Death. Durham \& London: Duke University Press.. 2002b South America The Amazon: The Forest of Marvels, (in) The Cambridge Companion to Travel Writing, pp. 122-139, Peter Hulme and Tim Youngs (eds.) . Cambridge: Cambridge University Press.

Whitehead, Neil L. and Nasser Abufarha,. 2008 Suicide, Violence, and Cultural Conceptions of Martyrdom in Palestine. Social Research, 75(2):395-415.

Whitehead, Neil L. and Peter Sigal n.d. Ethnopornography - Anthropology, Sexuality and Colonial Knowing. Duke University Press.

Wilensky, Harold L . 1997 Report from the Field Social Science and the Public Agenda: Reflections on the Relation of Knowledge to Policy in the United States and Abroad. Journal of Health Politic, Policy and Law, 22(5): 1241-1265. 
